\title{
Pembuatan Pakan Komplit Silfer dan Pupuk Organik sebagai Alternatif Penyedia Pakan dan Pupuk Bagi Petanipada Masa Pandemi COVID-19
}

\author{
Syamsul Bahri', Nurmi ${ }^{2}$ \\ ${ }^{1,2}$ Universitas Negeri Gorontalo, Jl. Jend. Sudirman No. 6 Dulalowo Timur, Kota \\ Tengah, Kota Gorontalo, Indonesia \\ email: syamsul.bahri@ung.ac.id, hafidnurmi@gmail.com
}

\begin{abstract}
Abstrak
Upaya peningkatan produksi pertanian untuk memenuhi kebutuhan pangan menghadapi tantangan besar terutama dalam hal penyediaan pakan berkualitas tinggi dan penyediaan pupuk yang ramah lingkungan. Kegiatan ini bertujuan untuk memberikan penyuluhan tentang manajemen pemeliharaan sapi potong, kesehatan ternak, seleksi dan perkawinan ternak dan pelatihan teknologi pembuatan pakan ternak sapi potong (pakan komplit silfer), memberikan penyuluhan tentang budidaya tanaman pangandan pelatihan tentang teknologi pembuatan pupuk tanaman pangan (pupuk organik), memberikan sosialisasi pencegahan wabah penyakit covid-19, dan membantu program-program Kecamatan terutama yang berkaitan dengan disiplin ilmu setiap mahasiswa peserta Proyek di Desa "Kampus Merdeka". Metode pelaksanaan kegiatan meliputi: persiapan, pembekalan, dan pelatihan. Pelaksanaan pelatihan pembuatan pakan komplit silfer dan pembuatan pupuk organik dilakukan oleh mahasiswa didampingi oleh dosen pembimbing lapangan.Pembuatan pakan komplit silfer yaitu dengan melayukan bahan-bahan berupa tanaman yang baru dipanen selama 3-12 jam untuk mengurangi kandungan airnya, mencacah tanaman dengan ukuran 1-5 cm, mencampur bahan yang sudah dicacah dengan bahan konsentrat lainnya lalu dimasukkan kedalam silo atau kantung plastik lalu dipadatkan dan ditutup rapat. Proses fermentasi berlangsung selama 21 hari.Metode pembuatan pupuk organik padat menggunakan metode fermentasi dengan bahan baku limbah ternak dan limbah tanaman. Pembuatan pupuk organik dilakukan dengan cara semua bahan dicampurkan secara merata dan dimasukkan kedalam wadah kompos. Pemeraman berlangsung dalam waktu 21 hari, dimana setiap minggu dilakukan pembalikan hingga proses pengomposan dapat berlansung secara baik. Adapun pembuatan pupuk organik cair menggunakan bahan dasar air kelapa yang difermentase dengan bantuan mikroba. Hasil pengabdian berupa pakan komplit silfer dan pupuk organik yang siap digunakan oleh mitra.Berdasarkan hasil yang diperoleh dapat disimpulkan bahwapembuatan pakan komplit silfer dan pupuk organik di Kecamatn Tilongkabila dapat menjadi alternatif penyedia pakan ternak dan pupuk bagi petani.
\end{abstract}

Kata Kunci:pakan komplit silfer; pupuk organik padat; pupuk organik cair 


\begin{abstract}
Efforts to increase agricultural production to meet food needs face major challenges, especially in terms of providing high quality feed and providing environmentally friendly fertilizers. This activity aims to provide counseling on the management of beef cattle maintenance, livestock health, livestock selection and mating and training on technology for making beef cattle feed (complete feed silfer), providing counseling on cultivating pangandan plants and training on technology for making food crop fertilizers (organic fertilizers). , provide socialization for the prevention of the covid-19 disease outbreak, and assist District programs, especially those related to the discipline of each student participating in the Project in the Village "Independent Campus" Methods of implementing activities include: preparation, provisioning and training. The training of complete feed silfer making and organic fertilizer production is carried out by students accompanied by field supervisors. The manufacture of complete feed silfer is by withering the ingredients in the form of freshly harvested plants for 3-12 hours to reduce their water content, chopping plants with sizes $1-5 \mathrm{~cm}$, mix the chopped material with other concentrated ingredients then put it in a silo or plastic bag then compact it and close it tightly. The fermentation process lasts for 21 days. The method of making solid organic fertilizer uses the fermentation method with raw materials of livestock waste and plant waste. Organic fertilizer is made by mixing all the ingredients evenly and putting them in a compost container. Curing takes place within 21 days, where every week is reversed until the composting process can take place properly. As for the manufacture of liquid organic fertilizers using the basic ingredients of fermented coconut water with the help of microbes. The service results in the form of complete feed silfer and organic fertilizers that are ready for use by partners. Based on the results obtained, it can be concluded that the manufacture of complete silfer feed and organic fertilizers in Tilongkabila District can be an alternative. provider of animal feed and fertilizer for farmers.
\end{abstract}

Keywords: complete feed silfer; solid organic fertilizer; liquid organic fertilizer

(C) 2021 Syamsul Bahri, Nurmi Under the license CC BY-SA 4.0 Correspondence author: Syamsul Bahri, syamsul.bahri@ung.ac.id, Gorontalo, Indonesia

\title{
PENDAHULUAN
}

Peningkatan produksi pertanian dalam upaya memenuhi kebutuhan pangan menghadapi tantangan lebih besar di masa 
sekarang dan masa yang akan datang. Di satu sisi kebutuhan konsumsi pangan dari tahun ke tahun terus mengalami peningkatan akibat jumlah penduduk yang semakin bertambah dan perbaikan ekonomi masyarakat. Di sisi lain produksi pangan belum mampu memenuhi kebutuhan pangan dan cenderung mengalami penurunan akibat laju penyusutan lahan pertanian yang kian cepat sebagai dampak dari adanya alih fungsi lahan.

Mengamati data pertambahan penduduk, kebutuhan pangan dan jumlah produksi pangan nasional khususnya jagung dan sapi potong, terjadi kesenjangan antara permintaan dan ketersediaan pangan sehingga perlu dikembangkan solusi peningkatan produksi agar kebutuhan pangan dapat terpenuhi dan produksi dalam negeri tercapai. Hanya saja upaya peningkatan produksi jagung mengalami kendala terutama karena sebagian besar areal tanaman jagung berada pada lahan kering yang memiliki produktivitas rendah.

Pengembangan tanaman jagung di lahan kering banyak terkendala pada kemampuan petani yang terbatas dalam mengadakan pupuk dan sangat tergantung pada penggunaan pupuk anorganik yang efeknya cepat terlihat.Namun penggunaannya secara terus-menerus dan tidak terkontrol bisa mengakibatkan kesuburan tanah semakin menurun, sehingga pilihan yang aman adalah dengan menggunakan pupuk organik.

Penggunaan pupuk organik akan menciptakan lahan pertanian menjadi lebih terlanjutkan (sustainable agriculture) sebab usahatani yang hanya mengandalkan pupuk buatan saja tanpa disertai pupuk organik, akan menimbulkan pengaruh buruk terhadap sifat fisika tanah yang pada akhirnya akan menurunkan produktivitas lahan. 
Usaha pengembangan sapi potong banyak terkendala pada ketersediaan pakan khususnya rumput dan legum. Ketersediaan pakan hijauan pada suatu daerah banyak dipengaruhi oleh perubahan fungsi lahan (lahan yang sebelumnya sebagai lahan penggembalaan atau sumber hijauan pakan menjadi lahan permukiman, lahan untuk tanaman pangan dan tanaman industri), dan pengaruh iklim dimana produksi hijauan melimpah pada saat musim hujan dan sangat kurang sampai terjadi paceklik di musim kemarau. Kondisi hijauan yang melimpah pada musim hujan khususnya limbah pertanian dapat dimanfaatkan sebagai pakan.

Bahan pakan dari limbah pertanian mengandung kadar protein yang rendah dan serat kasar yang tinggi sehingga sulit dicerna (Natsir, 2012). Selanjutnya Krishna dan Umiyasih (2007) menyatakan bahwa hasil sisa tanaman pertanian mempunyai kualitas yang rendah sehingga ternak yang memperoleh pakan asal sisa tanaman pertanian dalam waktu yang cukup lama produktivitas ternak yang dihasilkan menjadi rendah. Hasil sisa tanaman pertanian yang cukup melimpah tetapi masih jarang digunakan sebagai bahan pakan ternak adalah jerami jagung yang mengandung lignoselulosa yang terdiri dari lignin, selulosa, dan hemiselulosa (Yulistiani, 2010).

Pengolahan bahan pakan berserat berupa jerami yang dilakukan sebelum diberikan pada sapi (pradigesti) merupakan upaya untuk menaikkan kualitas dan kecernaannya (Natsir, 2012; Mayulu, 2014). Pemberian jerami jagung hasil pradigesti dapat dilakukan secara terpisah dengan konsentrat atau bersamaan (Utomo, 2012). Pemberian bahan pakan berserat (jerami jagung) dapat dilakukan dalam keadaan segar atau dalam bentuk awetan sebagai teknologi penyiapan pakan 
yang tidak hanya tahan simpan, tetapi juga mengandung nutrien yang sesuai dengan kebutuhan ternak. Teknologi pakan komplit dalam bentuk silase fermentasi (silfer) merupakan alternatif cara penyiapan pakan yang lazim diterapkan, karena selain lebih tahan simpan dan pembuatannya dapat dilakukan setiap saat tanpa dipengaruhi oleh musim.

Berdasarkan hasil survai awal di lokasi pengamatan, Kecamatan Tilongkabilamerupakan salah satu wilayah yang ketika musim kemarau sering juga terjadi kebakaran hutan akibat pembukaan lahan baru. Petani umumnya melakukan pembakaran lahan sebab disamping ingin membersihkan lahan dalam waktu singkat juga menganggap apabila vegetasi tanaman diatas lahan dibakar maka abu pembakaran dapat menyuburkan lahan pertanian untuk penanaman berikutnya.

Hasil wawancara dengan Pemerintah Kecamatan menyatakan produktivitas sapi potong di wilayahnya masih cukup rendah sebab jumlah pakan yang dikonsumsi sehari-hari masih kurang dari kebutuhan terutama disaat musim kemarau. Produktivitas hijauan masih rendah sebab lahan untuk penanaman rumput dan leguminosa terbatas dan hanya ditanami tanaman pangan, hortikultura, dan perkebunan. Kekurangan pakan sapi dipenuhi dengan mengkonsumsi rumput liar dan batang pisang yang kualitas nutrisinya masih cukup rendah. Kekurangan nutrisi juga mempengaruhi kesehatan ternak dengan timbulnya berbagai penyakit ternak seperti malnutrisi, cacingan, kulit terkelupas, mencret, yang berujung pada kematian ternak.

Dalam rangka mengatasi permasalahan di KecamatanTilongkabila, solusi yang ditawarkan adalah melakukan Pembuatan Pakan Komplit Silfer dan Pupuk Organik Sebagai Upaya Penyediaan Pakan Ternak 
dan Pupuk Tanaman Di Kecamatan Tilongkabila Kabupaten Bone Bolango. Bentuk kegiatan yang akan dilakukan adalah menyiapkan bahan dan peralatan yang akan digunakan dalam pembuatan pakan dan pupuk berupa jerami tanaman pangan dan feces ternak yang ada di KecamatanTilongkabila.

\section{METODE PELAKSANAAN}

\section{Persiapan dan Pembekalan}

Dalam persiapan dan pembekalan program Proyek di Desa "Kampus Merdeka"ini dibagi menjadi dua tahap yaitu mekanisme pelaksanaan kegiatan dan materi pembekalan kepada mahasiswa.Mekanisme pelaksanaan kegiatan meliputi: 1) Survei calon lokasi Proyek di Desa "Kampus Merdeka", 2) Penyusunan dan pengusulan proposal Proyek di Desa "Kampus Merdeka"ke LPPM, 3) Perekrutan Mahasiswa peserta Proyek di Desa "Kampus Merdeka", 4) Pembekalan (coaching) dan pengasuransian mahasiswa, 5) Pengambilan perlengkapan mahasiswa, 6) Pelepasan dan pengantaran, serta penyerahan mahasiswa Proyek di Desa "Kampus Merdeka"ke lokasi, 7) Monitoring dan evaluasi oleh DPL, dan 9) Penarikan mahasiswa dari lokasi KKN. Adapun materi pembekalan menyangkut pengenalan sumber pakan ternak dan pupuk organik, carapembuatan pakan komplit silfer dan pupuk organik, cara Penggunaan pakan komplit dan pupuk organik, teknik budidaya tanaman pangan dan manajemen pemeliharaan ternak sapi potong

\section{Uraian Program KKN Tematik}

Langkah-langkah dalam bentuk program kerja yang 
dilaksanakan di lokasi Proyek di Desa "Kampus Merdeka"meliputi beberapa hal yaitu program penyediaan bahan baku hijauan (jerami jagung dan legum) dan bahan konsentrat (dedak padi, tepung jagung, ampas tahu) dan feces ternak sapi potong, pembuatan pakan komplit silfer, dan pembuatan pupuk organik.

Metode yang digunakan dalam melakukanpemberdayaan kelompok mitra sasaran adalah teknik pembelajaran dalam bentuk pemberian teori dan simulasi kepada warga desa yang menjadi mitra sasaran dan selanjutnya praktek secara langsung bersama mahasiswa dan warga desa.

Langkah-langkah operasional yang diperlukan untuk mengatasipermasalahan di Kecamatan Tilongkabila antara lain:

\section{- Pelatihan Pengenalan Sumber Bahan Baku Pembuatan Pakan Komplit dan Pupuk Organik.}

Kegiatan ini dilakukan di Aula Kantor Kecamatan dan peserta adalah warga yang terpilih untuk mengikuti program pengenalan sumberdaya pakan dan pupuk organik.Pemateri adalah mahasiswa peserta Proyek di Desa "Kampus Merdeka"dan didampingi oleh Dosen Pembimbing Lapangan. Materi yang diberikan adalah pengenalan semberdaya pakan dan pupuk, carapenyediaan, dan carapemanfaatan.

\section{- Pembuatan Pakan Komplit Silfer.}

Pembuatan pakan komplit silfer yaitu dengan melayukan bahanbahan berupa tanaman yang baru dipanen selama 3-12 jam untuk mengurangi kandungan airnya, mencacah tanaman dengan ukuran 1-5 cm, mencampur bahan yang sudah dicacah dengan bahan 
konsentrat lainnya lalu dimasukkan kedalam silo atau kantung plastik lalu dipadatkan dan ditutup rapat. Tidak boleh ada ruang udara. Proses fermentasi berlangsung selama 21 hari. Apabila proses fermentasi berjalan baik, ditandai dengan tidak adanya jamur dan bau asam. Setelah 21 hari silase siap digunakan.

\section{- Pembuatan Pupuk Organik.}

Metode pembuatan pupuk organik menggunakan metode fermentasi dengan bahan baku limbah ternak dan limbah tanaman. Pembuatan pupuk organik membutuhkan wadah berupa lubang dengan ukuran lebar $1 \mathrm{~m}$. Panjang $2 \mathrm{~m}$ dan tinggi 1,2 $\mathrm{m}$. Semua bahan dicampurkan secara merata dan dimasukkan kedalam wadah kompos. Pemeraman berlangsung dalam waktu 21 hari, dimana setiap minggu dilakukan pembalikan hingga proses pengomposan dapat berlansung secara baik.Adapun pembuatan pupuk organik cair menggunakan bahan dasar air kelapa yang difermentase dengan bantuan mikroba.

Pekerjaan yang dilakukan oleh mahasiswa peserta Proyek di Desa "Kampus Merdeka"selama 45 hari dihitung dalam satuam Jam Kerja Efektif Mahasiswa (JKEM). Setiap mahasiswa melakukan pekerjaan sebanyak $288 \mathrm{JKEM}$ selama 45 hari atau $8640 \mathrm{JKEM} / 30$ mahasiswa selama 45 hari. Apabila dirata-ratakan sebanyak 6,4 jam/hari selama 45 hari (1,5 bulan). Total JKEM tersebut didistribusi kedalam 4 program kerja yang akan dilaksanakan selama berada di lokasi Proyek di Desa "Kampus Merdeka".

\section{Rencana Aksi Program}

Program pelatihan pembuatan pakan komplit silfer dan pupuk organik di wilayah Kecamatan Tilongkabila merupakan solusi untuk 
memaksimalkan pemanfaatan limbah tanaman pangan dan limbah peternakan yang selama ini tidak hanya menjadi permasalahan lingkungan di masyarakat namun juga menjadi sumber hijauan makanan ternak dan pupuk organik tanaman pangan.

Pakan komplit silfer dan pupuk organikyang dihasilkan selama Proyek di Desa "Kampus Merdeka"perlu terus disosialisasikan dan disuluhkan pada petani dan peternak lainnya agar tetap menjadi solusi penyediaan pakan dan pupuk. Dukungan dari pemerintah Kecamatan berupa intervensi dan regulasi pemanfaatan dan penyediaanpakan komplit dan pupuk organik sangat diperlukan. Beberapa lembaga yang dapat terlibat adalah pemerintah Desa setempat, pemerintah Kecamatan, Dinas yang terkait dengan pertanian, peternakan, maupun Lembaga Swadaya Masyarakat (LSM) yang bergerak dibidang pertanian, peternakan dan perlindungan/pelestarian alam. Kegiatan ini juga sebaiknya didukung dari Ristek Dikti dengan skim pengabdian yang dananya lebih besar seperti KKN-PPM, Program Pengembangan Desa Mitra (PPDM) agar pengetahuan warga desa tentang pemanfaatan limbah pertanian dan peternakan menjadi pakan komplit silfer dan pupuk organik dapat diaplikasikan lebih luas lagi.

\section{HASIL DAN PEMBAHASAN}

\section{HASIL}

\section{Pembuatan Pakan Komplit Silfer}

Pembuatan pakan komplit silfer didahului dengan pemberian teori di aula kantor desa dalam bentuk penyuluhan tentang pembuatan pakan komplit silfer. Setelah para peserta telah memahami cara pembuatan pakan komplit silfer, maka dilanjutkan dengan praktek 
pembuatan pakan komplit silfer dengan bahan utama jerami jagung dan daun gamal. Pembuatan pakan komplit silfer dilakukan bersama mahasiswa peserta KKN-MB dari UNG dan beberapa warga desa Kecamatan Tilongkabila yang tertarik untuk mengetahui cara pembuatan pakan komplit silfer. Selama kegiatan pembuatan, peserta aktif untuk bekerjasama dalam sejak persiapan alat dan bahan dan pembuatan pakan komplit silfer. Secara detail, tahapan pembuatan pakan komplit silfer, meliputi:

1. Menyiapkan bahan utama pakan komplit silfer yaitu jerami jagung sebanyak $60 \mathrm{~kg}$ dan daun gamal $15 \mathrm{~kg}$.

2. Menyiapkan bahan-bahan tambahan diantaranya konsentrat 25 $\mathrm{kg}, \mathrm{EM}-4$ + molasses + air secukupnya.

3. Jerami jagung dan daun gamal dicacah (semakin kecil semakin baik), kemudian dihamparkan diatas terpal dan diatasnya ditabur konsentrat.

4. Buat larutan tetes tebu(Molases ) dan Probiotik (EM 4) dengan air secukupnya.

5. Semprotkan/Percikkan larutan molasses dan EM-4 keatas hamparan jerami jagung dan daun gamal, selanjutnya dicampur hingga merata dan bila perlu ditambah air hingga kadar air campuran mencapai $60 \%$.

6. Untuk mengukur Kadar Air, adonan dikepalkan ditangan bila tangan basah tapi air tidak menetes berarti takaran kadar air sudah cukup.

7. Masukkan silase ke dalam silo, dipadatkan dan tutup rapat (tidak ada udara luar yang masuk ). 
8. Pakan Komplit hasil fermentasi ini dapat digunakan setelah 3 minggu proses fermentasi berlangsung.

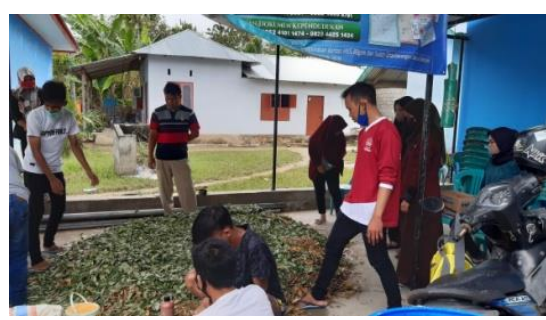

Jerami Jagung dan Daun Gamal

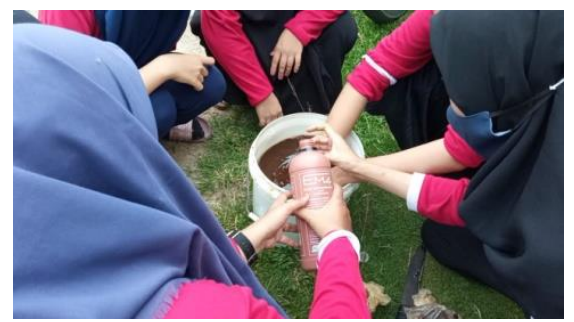

Mencampur EM-4, gula dan air

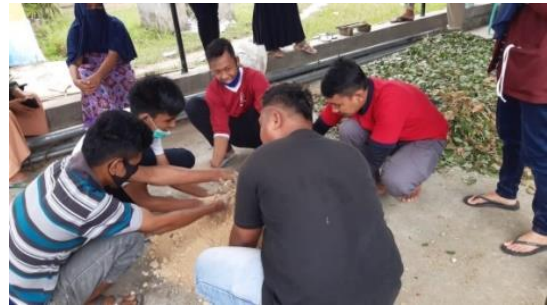

Pencampuran Konsentrat

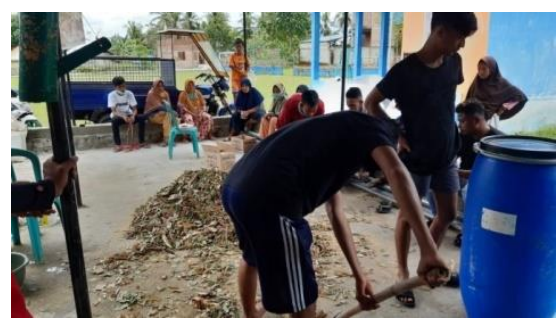

Pencampuran Bahan Silase

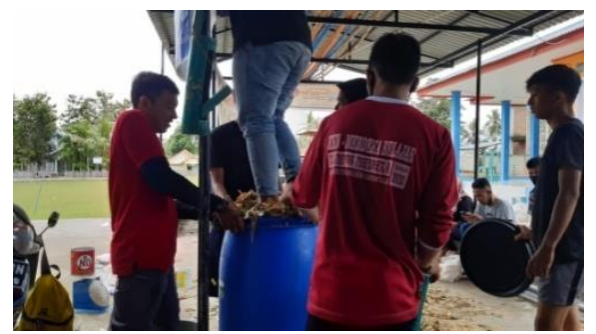

Pemasukan Silase ke dalam Silo

\section{Pembuatan Pupuk Organik}

Proses pembuatan pupuk organik meliputi beberapan tahapan, yaitu:

- Menyiapkan bahan utama pupuk organik yaitu pupuk dari kotoran sapi sebanyak $150 \mathrm{~kg}$.

- Menyiapkan bahan-bahan tambahan diantaranya katul/dedak 5 kg, gula pasir $1 \mathrm{~kg}$, EM-4 $250 \mathrm{ml}$ atau 25 sendok makan, air secukupnya. 
- Mencampur kotoran ternak, dedak/bekatul hingga merata, dengan cara ditumpuk dengan susunan tumpukan berurut dari volume terbanyak paling dibawah (kotoran ternak) diikuti dengan dedak padi.

- Melarutkan EM-4 sebanyak $250 \mathrm{ml}$ dan gula pasir ke dalam air, sambil diaduk agar lebih merata.

- Menyiramkan larutan EM4 + gula, air, secara perlahan merata ke dalam campuran kotoran ternak + dedak hingga kandungan air di campuran mencapai $30-40 \%$. Tandanya bila campuran dikepal air tidak keluar dan bila kepalan dibuka campuran tidak buyar.

- Setelah seluruh bahan tercampur merata, dihamparkan di atas lantai kering dengan ketebalan $15-20 \mathrm{~cm}$, lalu tutup dengan terpal selama 14 hari. Agar suhu campuran tidak terlalu panas selama fermentasi, dilakukan pengadukan setiap hari hingga suhu dapat dipertahankan pada kisaran $45^{\circ} \mathrm{C}-50^{\circ} \mathrm{C}$.

- Tiga minggu setelah fermentasi, pupuk organik telah siap digunakan.

Pupuk organik dari kotoran ternak yang telah "matang", ditandai dengan beberapa indikator, diantaranya:

- Warnanya berubah menjadi lebih hitam menyerupai warna tanah

- Ketika digenggam dan kemudian dilepas, pupuk sudah tidak menggumpal lagi

- Pupuk sudah tidak berbau kotoran lagi namun sudah berbau seperti bau tanah

- Suhu pupuk dibawah $40^{\circ} \mathrm{C}$

- Ratio C/N adalah antara 10 sampai 12.

- $\quad$ pH pupuk berada dalam kisaran netral yaitu 7

- Volume dan berat pupuk menyusut dibandingkan dengan waktu pertamakali dibuat. 


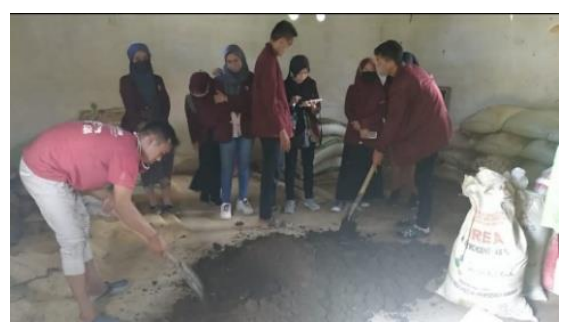

Kotoran Ternak

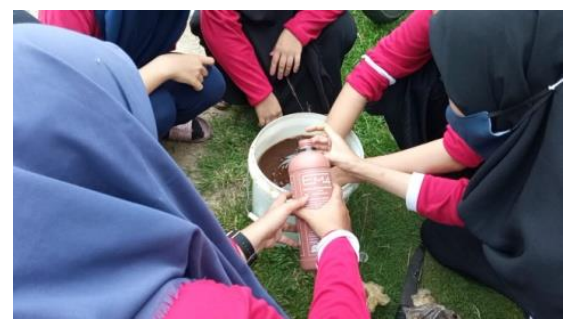

Mencampur EM-4, gula dan air

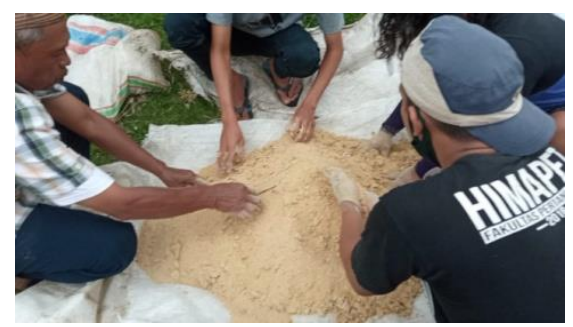

Dedak padi

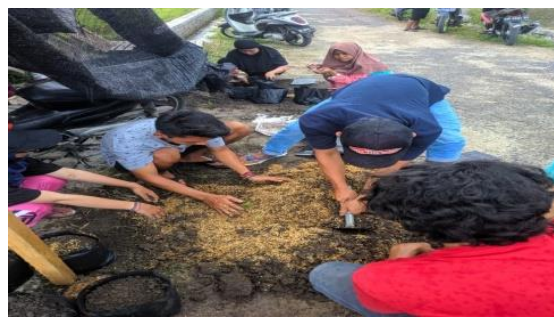

Pupuk organik siap digunakan

\section{PEMBAHASAN}

\section{Pakan Komplit Silfer Sebagai Pakan Ternak}

Pakan komplit adalah suatu teknologi formulasi pakan yang mencampur semua bahan pakan yang terdiri dari hijauan (limbah pertanian) dan konsentrat yang dicampur menjadi satu tanpa atau hanya sedikit tambahan rumput segar. Pakan Komplit adalah ransum berimbang yang telah lengkap untuk memenuhi kebutuhan nutrisi ternak, baik untuk pertumbuhan, perawatan jaringan maupun produksi.Dalam pemberiannya, ransum ini tidak memerlukan tambahan apapun kecuali air minum.Dengan pemberian pakan komplit, lebih praktis dan sangat menghemat tenaga kerja serta petani tidak perlu lagi setiap hari mencari rumput.

Hasil sisa tanaman pertanian yang cukup melimpah tetapi masih jarang digunakan sebagai bahan pakan ternak adalah jerami jagung 
yang mengandung lignoselulosa yang terdiri dari lignin, selulosa, dan hemiselulosa (Yulistiani, 2010). Pengolahan bahan pakan berserat berupa jerami yang dilakukan sebelum diberikan pada sapi (pradigesti) merupakan upaya untuk menaikkan kualitas dan kecernaannya (Natsir, 2012; Mayulu, 2014). Pemberian jerami jagung hasil pradigesti dapat dilakukan secara terpisah dengan konsentrat atau bersamaan (Utomo, 2012). Pemberian bahan pakan berserat (jerami jagung) dapat dilakukan dalam keadaan segar atau dalam bentuk awetan sebagai teknologi penyiapan pakan yang tidak hanya tahan simpan, tetapi juga mengandung nutrien yang sesuai dengan kebutuhan ternak. Teknologi pakan komplit dalam bentuk silase fermentasi (silfer) merupakan alternatif cara penyiapan pakan yang lazim diterapkan, karena selain lebih tahan simpan dan pembuatannya dapat dilakukan setiap saat tanpa dipengaruhi oleh musim.

\section{Pupuk Organik Sebagai Pembenah Tanah}

Sejarah penggunaan pupuk pada dasarnya merupakan bagian dari pada pertanian. Pupuk organik adalah pupuk yang tersusun dari materi makhluk hidup yang diolah melalui proses pembusukan (dekomposisi) oleh bakteri pengurai, seperti pelapukan sisa-sisa tanaman, hewan. Pupuk organik dapat berbentuk padat dan cair yang digunakan untuk memperbaiki sifat fisik, kimia, dan biologi tanah. Pupuk organik akan memberikan keuntungan karena bahan dasar pupuk organik berasal dari limbah pertanian dan peternakan. Pupuk organik merupakan bahan pembenah tanah yang paling baik disbanding bahan pembenah lainnya. 
Pupuk organik bersimulator EM4 yang diaplikasi pada lahan petani akan meningkatkan kualitas sifat fisik tanah, khususnya porositas tanah sehingga infiltrasi air menjadi baik ketika terjadi hujan. Peningkatan jumlah dan volume pori atau perbaikan porositas tanah juga dapat memperbaiki media perkembangan perakaran tanaman akibat menurunnya resistensi penetrasi tanah terhadap akar. Suntoro (2003) menjelaskan bahwa porositas tanah adalah ukuran yang menunjukkan bagian tanah yang tidak terisi bahan padat tanah yang terisi oleh air dan udara. Pengaruh bahan organik terhadap peningkatan porositas tanah berkaitan dengan status kadar air di dalam tanah. Penambahan bahan organik akan meningkatkan kemampuan tanah menahan air sehingga kemampuan menyediakan air tanah untuk tanaman meningkat. Selanjutnya Eddy Funderbeg (2001) dalam Sargiman dan Panjaitan (2013) mengemukakan bahwa peranan bahan organik secara fisik dapat diketahui sebagai (a) dinamisasi air, yaitu meningkatkan infiltrasi air, menurnkan laju evaporasi, meningkatkan kapasitas pengikatan air, terutama pada tanah berpasir, (b) struktur tanah, meliputi mengurangi crusting, terutama pada tanah bertekstur liat, memudahkan penetrasi akar, meningkatkan agregasi tanah, mencegah erosi, dan mengurangi pengerasan atau kepadatan tanah.

Penurunan kadar bahan organik tanah juga menyebabkan menurunnya sejumlah hara tanaman terutama hara $\mathrm{N}$ dan $\mathrm{P}$ serta terhambatnya aktivitas mikroba tanah. Selain itu, rendahnya kadar bahan organik tanah juga sering berkaitan dengan menurunnya sifatsifat fisik tanah, seperti struktur tanah yang masif atau lepas, kapasitas memegang air dan laju infiltrasi rendah, dan erosibilitas tanah yang tinggi. Beberapa hasil penelitian tentang penggunaan bahan organik 
yang dapat meningkatkan produksi tanaman jagung, kedelai, dan kacang hijau telah dilaporkan oleh sejumlah peneliti (Widowati, 2009).

\section{KESIMPULAN}

Berdasarkan hasil dan pembahasan disimpulkan pembuatan pakan komplit silfer dan pupuk organik di Kecamatn Tilongkabila dapat menjadi alternatif penyedia pakan ternak dan pupuk bagi petani.

\section{UCAPAN TERIMA KASIH}

Ucapan terimakasih disampaikan kepada Direktur LPM UNG yang telah memfasilitasi dalam hal pendanaan untuk pelaksanakan kegiatan KKN pengabdian ini. Demikian pula ucapan terima kasih disampaikan kepala Desa Lonuo, Bongopini, Motilango, dan Tamboo yang telah menyiapkan tempat untuk pelaksanaan kegiatan, dan kepada semua pihak yang telah ikut membantu yang tidak sempat disebutkan satu persatu, disampaikan terima kasih

\section{REFERENCES}

Badan Pusat Statistik (BPS). 2019. Kabupaten Bone Bolango Dalam Angka 2019. Badan Pusat Statistik Kabupaten Bone Bolango.

Badan Pusat Statistik (BPS). 2018. Kecamatan Tilongkabila Dalam Angka 2018. Badan Pusat Statistik Kabupaten Bone Bolango.

Bahri, S. 2018. Pemanfaatan Silase Ransum Komplit Berbasis Jerami Jagung Sebagai AlternatifPenyedia Pakan Penggemukan Sapi Bali. Laporan Hibah Disertasi Doktor. Universitas Negeri Gorontalo

Muhamad, I., Sayuti, M., Laya, N.K., Bahri, S. 2018. Performans Sapi Bali Jantan Yang Diberi Silase Ransum Komplit Berbahan Dasar 
Jerami Jagung dan Daun Gamal. Prosiding Seminar Nasional Integrated Farming System, Gorontalo 25-26 November 2018

Suyuti, M., S. Bahri., F. Ilham. 2018. Master Plan Mini Ranch Peternakan Terpadu Kabupaten Gorontalo Utara. Laporan Hasil Kajian Kerjasama Dinas Peternakan dan Kesehatan Hewan Gorontalo Utara dan Fakultas Pertanian Universitas Negeri Gorontalo

Suntoro Wongso Atmojo, 2003. Peranan Bahan Organik Terhadap Kesuburan Tanah serta Upaya Pengelolaannya. Pidato Pengukuhan Guru Besar, Universitas Sebelas Maret. Surakarta. Diakses 2 November 2016

Sargiman, G. dan T.W.S. Panjaitan.2013. Pengaruh Penggunaan Pupuk Organik Hayati Terhadap Perbaikan Sifat Fisik Tanah di Kecamatan Pare Kabupaten Kediri. Jurnal Agroknow, Vol. 1. No. $1: 7-12$

Widowaty, L.R. 2009. Pengaruh Pupuk Organik Terhadap Efisiensi Pemupukan dan Tingkat Kebutuhannya untuk Tanaman Sayuran pada Tanah Inceptisol Ciherang-Bogor. Jurnal Tanah Tropika, Vol. 14. No. $3: 221$ - 228 